\title{
VARIOUS PROBLEMS OF EDUCATIONAL PROCESS IN MULTILINGUAL DAGESTAN UNDER THE GLOBOLIZATION CONDITIONS: HISTORY AND MODERNITY
}

\author{
(C) Maida G. Mustafaeva, Elmira Sh. Musaeva, Zarema S. Mustafaeva
Dagestan state pedagogical university. Makhachkala, Russian Federation science-almanac@mail.ru

Some problems in the educational space of the Dagestan Republic have been considered in retrospective. The unified educational space is affected by globalization, informatization, as well as socio-economic, socio-cultural factors and political changes in society. The paradigm shift in education is dictated by the need to overcome the destructive pragmatism of the technical and economic interest in nature, culture and personality, to ensure the transition of mankind to a new natural-sociocultural attitude of a protective-constructive type. The authors note that the tendencies of modern society have brought a new value to the contemporary arena - polysubjectivity, because the directions of the educational policy that are numerous and important for the welfare of the state can neither be formulated, nor even be provided only by the forces of the state. The conclusion, expressed by the authors about the mono-subjectivity of the state educational policy in Russia, Dagestan points to the need to ensure the education openness as a state-public system, the transition from the paternalistic model to the model of mutual responsibility in education, the strengthening of the role of all actors and their interaction.

Key words: education, historical experience of education formation in national (multilingual) regions of Russia, spiritual educational schools of Russia.

\section{[М.Г. Мустафаева, Э.Ш. Мусаева, 3.С. Мустафаева}

Некоторые проблемы образовательного процесса в полиязычном Дагестане в условиях глобализации: история и современность]

Рассматриваются некоторые проблемы в образовательном пространстве республики Дагестан в ретроспективном плане. На единое образовательное пространство влияет глобализация, информатизация, а также социально-экономические, социально-культурные факторы и политические изменения в обществе. Смена парадигмы образования диктуется необходимостью преодолеть разрушительный прагматизм технико-экономического интереса к природе, культуре и личности, обеспечить переход человечества к новым природно-социокультурным отношением охранно-созидательного типа. Отмечается, что тенденции современного общества вывели на современную арену новую ценность полисубъективность, т.к многочисленные и важные для благополучия государства направления образовательной политика невозможно ни сформулировать, ни тем более обеспечить только силами государства. Аргументированный авторами вывод о моносубъективности государственной образовательной политики в России, Дагестане указывает на необходимость обеспечения открытости образования как государственно-общественной системы, перехода от патерналистской модели к модели взаимной ответственности в сфере образования, усиления роли всех субъектов и их взаимодействия.

Ключевые слова: образование, исторический опыт становления образования в национальных (полиязычных) регионах России, духовные образовательные школы Республики.

Maida G. Mustafaeva - Ph.D. of philosophy, professor. Dagestan state pedagogical university. Makhachkala, Russian Federation.

Elmira S. Musaeva - candidate of philosophy, assistant professor. Dagestan state pedagogical university. Makhachkala, Russian Federation.

Zarema S. Mustafaeva - candidate of philosophy, associate professor. Dagestan state pedagogical university. Makhachkala, Russian Federation.

Мустафраева Маида Ганифраевна - доктор фрилософских наук, профессор. Дагестанский государственный педагогический университет. Махачкала, Россия. 
Мусаева Эльмира Шекералиевна - кандидат фрилософрских наук, доцент, Дагестанский государственный педагогический университет. Махачкала, Россия.

Мустафраева Зарема Сиражудиновна - кандидат философрских наук, доцент Дагестанский государственный педагогический университет. Махачкала, Россия.

Under the education in the RF Law "about education" one considers a purposeful process of training and education in the in interests of a person, society, government, accompanied with affirmation of students achievements of educational levels, established by the government [4, p.25]. Education as a socio-cultural phenomenon has passed a certain way of development and formation under the influence of the society needs, because it has always revealed the most important social functions. As A.A. Bodalev marks, education function of regional systems and national traditions development [10, p.48]. Dagestan, the new stage of education development in Dagestan, the role of national intelligentsia in the educational process, monosubjectivity, paradigm.

Education is considered to be the complex, sociocultural phenomenon, that is why the education theory development requires attraction of all spectrum of socio-humanitarian studies, clarification of the conceptual questions on the bases of integrative interdisciplinary knowledge, systematized on the philosophic-methodological bases. The current state of the educational space in Dagestan was preceded by a long, complex and contradictory path of development. Its comprehension and coverage for many decades suffered from methodological one-sidedness and ideological. Everything positive in the historical and spiritual experience of the so-called small nationalities was ignored, so it did not fit into the concept of Soviet ideology. Many monuments of national culture were given nihilistic sentences only on the grounds that they were allegedly inspired by the "Eastern", "Muslim" spirit, which was interpreted as the influence of reaction, ignorance and obscurantism. This position was linked with Eurocentric and not justified neglect of the "lagged East" [13, p. 41-47].

Meanwhile, Eastern literature in the form of collections and libraries accumulated in Dagestan for centuries. It was not only theological, doctrinal literature, but also the most important sources in various fields of knowledge,"Encyclopedia of natural knowledge of the Muslim world" of the Arab historian Tabari, "Revival of faith" of al - Ghazali, "Inception" of Euclid, etc. As G.Sh Kaimazarov marks the Muslim education system obtained in Dagestan the widespread occurrence and the Muslim school becomes the most important center of training and education of the rising generation. Maktab and madrasa were the main links of the Muslim education system in Dagestan. Along with the above-mentioned "organized" education forms in Dagestan, the home teaching of the Koran reading for children obtained the widespread. Girls represented the significant part of students in the home "Koran schools" in the late XIX-beginning of XX c. The girls practically were not taught to write.

The number of Primacy schools was unstable. They opened at any time of the year, depending on the availability of students at the discretion of the lecturer-mule, it also depended on the closing time of the school. Besides, the students passed from one lecturer to the other, who was more famous. That is why Muslim schools, especially home - Koranic were badly registered, but undoubtedly, Dagestan was the region full of the Muslim schools in the all Caucasus [5, p.118]. Traditional for Dagestan spiritual school with teaching in the Arabic language was the main form of education. Dagestan accounted for half of all Muslim schools in the Caucasus. "This pile of bare rocks was perhaps the most literate place in the Caucasus", wrote the historian M. Pokrovsky. "In Dagestan, the teaching is accessible to every mountain boy", testified "The Collection of information about the Caucasian mountaineers [8,p.25]. The course of Muslim education in Dagestan along with theology, includes such disciplines as jurisprudence, logic, rhetoric, grammar and stylistics of the Arabic language, the doctrine of versification, algebra, astronomy, geography. Moreover, the bases of Indian, Persian and Western European philology and philosophy were available to Dagestanis: the views of Aristotle and Plato, the ideas of Voltaire and Hugo, and others. "The 
Arab book for Dagestan was not an imported ornament of external scholarship, it really lived" (I.Krachkovsky). It generated from the local population an interest in scientific creativity. The educated Dagestan nominated outstanding thinkers and scholars: Shaaban from Obod, Musalava from Kudutlya, Taygib from Kharakhi, Mohammed from Yaragi, Damadan from Megeb, Dibir-Kadi from Khunzakh and many others whose works on history, philosophy, law, theology, and philology were studied, mastered, commented by contemporaries and later generations. Many of them were widely known in the Muslim East. The academician Orientalist I.Krachkovsky stressed that "The Dagestanis and outside their homeland, where fate threw them, proved to be universally recognized authorities for the representatives of the entire Muslim world" [7,p.20].

A new stage in the development of the mountainous Dagestani society was connected with the joining of Dagestan to Russia. Under the influence of prominent representatives of Russian science (A. Berge, A. Neverovsky, V. Dokuchaev, N. Pirogov, P. Uslar, etc.), remarkable scientists D. Shikhaliev, Z. Kazanfar, A. Chirkeyevsky, A. Alcadari, M. Amirov, B. Dalgat, etc. were risen. With their help P.Uslar managed to create the creation of grammars of Avar, Dargin, Lezgin, Lak, and Tabasaran languages, to publish a number of mountain folklore masterpieces. In the second half of the 20th c. there were first samples of Dagestani alphabets, textbooks - grammar, books for reading, etc.

The first rural schools of the secular direction appeared there. An enlightened national intelligentsia was formed from the Dagestanis, who received higher education in St. Petersburg, Moscow, Kazan, Istanbul, Cairo, Paris, etc. In the Soviet period the system of education and science of Dagestan became a matter of state administration. The fundamental changes occurred in the result of writing translation of Dagestan people from Arabic to Latin (1928), and then to Russian graphical bases. Along with an extensive network of primary and secondary schools, technical schools and colleges for the sectoral training of personnel were created. The system of vocational training was established. In the early 30's, the first universities were opened. There were also scientific institutions. The creation of the Dagestan Scientific Research Institute for the Study of the Cultural Heritage of the Dagestan People in 1924 was a major event.

Today, science in Dagestan is represented by the Dagestan Scientific Center of the Russian Academy of Sciences, which includes more than ten independent research institutes carrying out fruitful research in almost all the leading fields of modern science, by five higher educational institutions.

In 1998 in the international document "The world declaration about higher education for XXI century: approaches and practical measures" was marked that success of educational policy depends on informing about all subjects, including community, state and private sectors of economics, parliament, mass media, governmental and non-governmental organizations, and also the students and their families, other representatives of society, interested in the higher education. In this connection the question, how the other subjects of educational space react to reformation and modernization of education, represents a special interest [2,p.47]. In accordance with the Law of the RF "About Education", the content of education should ensure the formation of students "a picture of the world that is adequate to the modern level of knowledge and the level of the educational program (level of instruction)" [9,p.2]. But the scientific approach is not able to provide a decent education because of its limitations. And society estimates, the vitality of the new generation, as a result of education, its constructive and creative attitude to itself and its social life. According to the modernization conception education system supplying is the priority of educational policy.

"Increasing of the lecturers professional level, training and formation of pedagogical block, corresponding to the modern life requirements, - primary challenge, necessary condition of Russia education system modernization" [6, p.19]. Consider the correspondence of the "pedagogical block" of educational institutions (EI) and institutions of additional education (IAE) of Makhachkala city to "the demands of modern life". Statistics show that "there is a sharp fall in the prestige of teaching work, primarily because of paltry wages", 
about $25 \%$ of people without education and relevant abilities come to educational institutions, and today the level of the quality of education is low, associated with the provision of education-Methodical literature, use of modern innovative, information technologies. "There are problems with the staffing, working in the old manner and with the old baggage of knowledge. The level of pedagogical skills and skills that form the basis of the professional skill of the lecturer, also wishes the best [11,p.46]. There is a sharp decline in the prestige of scientific, teaching and teaching work, primarily because of the meager wage.

We used sociological research materials. For example, on September 1, 2007, the lecturer receives a wage approximately equal to the subsistence minimum. Taking into account wages in the educational sphere, it is obvious that young prospective specialists will try to realize themselves in other kinds of activity or go outside the republic, Russia. So it was only in 2001-2002, almost 100 thousand young specialists left Russia. Sociological calculations show that by the time the concept of modernization is completed, the Russian school will remain virtually without lecturers of proper qualifications [11,p.24].

A. Shipilov, having analyzed the salary of the teaching staff since 1730 , comes to the conclusion that "a government that thus treats the maintenance and reproduction of its own intellectual potential in a modern high-tech world is not viable: unable to withstand competition from other powers, it will be destroyed" [12,p.40]. Within the framework of the national "Education" project realization, Grant support of lecturers and innovative educational institutions introduced since 2006. However, a more biased pattern of evaluating and summarizing the tenders for grants in our country does not contribute to the creation of a system of incentives for lecturers to actively participate in the modernization of education, improve their professionalism, use new technologies in the educational process. All this leads to a decrease in the prestige of teaching and research in modern society.

Consider another subject of the educational space - the student. The Concept of Modernization defines the main goal of education - "the preparation of a qualified employee of the appropriate level and profile, competitive in the labor market, competent, responsible, freely proficient in his profession and oriented in related fields of activity, capable to work effectively in the specialty at the level of world standards, ready for professional constant growth, social professional mobility" [6, p.19]

The survey data, carried out by the authors with the purpose of revealing the professional position of the schoolchildren, showed the incompatibility of the El graduates with the above mentioned requirements. 1480 schoolchildren of 9th-11th grades of the Makhachkala city El took part in the survey. $42 \%$ of respondents entered the university in 2007 . Under the studying the value-motivational sphere of the El students, the motives for entering a higher educational institution and choosing a particular specialty were revealed - one of the main indicators of the emerging attitude towards the profession. The conscious desire of the entrant to devote himself to the beloved work, contributes to more successful education in the university, the development of professionally important qualities. Superficial motivation (associated with the desire to follow other people's advice with pragmatic or prestigious considerations) does not ensure a genuine growth of personality in the chosen profession. During the research it was found out that the majority of the sample group $(65 \%)$ lacked initial professional motivation. The motivation for entering a university depends mainly on the parents views.

Based on the survey data, it is possible to draw conclusions about professional orientation-expectations of different respondents. More than $48 \%$ of the sample group hopes to become professionals in their business, $65 \%$ expect good salary, $32 \%$ - interesting work, about $38 \%$ are going to make a good career and $4 \%$ think that it will be difficult to find a job in the specialty [14]. The life plans of schoolchildren are closely related to professional orientation. From the total sample $85 \%$ after completing their studies at the university are going to work, $9 \%$ would like to continue their education, $6 \%$ dream of entering to postgraduate studentship, $34 \%$ organize their own business, $7 \%$ are concerned about the or- 
ganization of the personal life. The number of schoolchildren who want to go abroad varies between $3 \%$.

Value orientations, being one of the central personal educations, express the person's conscious attitude to social reality and, in this capacity, determine the broad motivation of his behavior, significantly influence on all aspects of his activity. Therefore, a profound analysis of a professional personality, his attitude to the world is impossible without studying the system of his value orientations. Thus, in the structure of the students' values, the greatest role is played by material well-being, or rather high wages. Of course, various schoolchildren categories in orientation, life plans and abilities differently relate to money. One part of the students calls money as a necessary condition for providing more or less acceptable living conditions, since they cannot count on financial assistance from their parents. For another part of schoolchildren money is important in itself, because without it they cannot realize their life and professional plans, for example, to open their own business (office, enterprise, etc.), to expand some financial or other activity. Here, money becomes a primary goal, without which it is impossible to realize further plans [1, p.27].

To identify differences in the views of lecturers and production workers, the author used the method of expert interview. The experts group, including 15 people, on the one hand were incorporated, those who directly deal with the educational process organization in the Makhachkala educational area: representatives of DIATPHR the city Education Department, principals, deputy principals of EU and UEE; on the other hand, employees of the Labor and Employment Administration (among them are specialists in various industries: the head of the personnel department, human resources specialists, economists and engineers). The questionnaire was based on the requirements for the graduate of the $\mathrm{El}$, University, which were formulated at the World Education Congress (1992, Portsmouth). In the questionnaire, it was proposed to evaluate the importance of the graduates qualities on a 10-point scale. The differences between the opinions of experts are most clearly manifested in the positions listed below.

The ability to carry out all activities defined by the state educational standard:

2.2. Foreign languages skill.

5.2. Availability of knowledge in related fields.

6.1. Consistency of good mood.

6.5. Sense of humor.

7.2. Driving license.

7.4. Athletic feats.

Lecturers put higher scores practically for all indicators. The exceptions were 2 points: readiness to implement their plan and bear responsibility for it; duty performances, the ability to obey, precisely perform instructions. Representatives of both samples highly appreciated the combination of theoretical knowledge and practical preparedness, knowledge of the Russian language, the ability to use information technology, conscientiousness and the desire for personal and professional development, responsibility for the performance of work. Low rates in both samples in the following positions: sports achievements, driving license, characteristics, ability to develop documentation. Having analyzed the differences in opinions, one can draw the following conclusions. EL lecturers believe that they should prepare widely erudite editors with good humanitarian training, with knowledge in related fields (7-7,3 points), for industrialists the grades for these indicators are lower. Lecturers more highly appreciate personal characteristics: balance, good humor, sense of humor, conscientiousness and activity. Employees of the enterprises note conscientiousness and diligence, and diligence is valued more than creative approach, independence and initiative.

There are fundamental differences according to the foreign language. In spite of the fact that Makhachkala is a port of international importance, Dagestan is the southern outpost of Russia, the employees - production workers put the foreign language knowledge to 21 place out of 31 possible. There are no fundamental differences on the positions reflecting 
the creative approach to business, the positive attitude to the profession and the technologies communication knowledge.

It is necessary to estimate situation, existing on the labor market over recent years, for interpretation of the obtained result. In the Soviet Union, the state guaranteed the receipt of a workplace for each graduate of a school that received a higher education. And the higher school for a long time trained specialists with a focus on a high level of theoretical training, not paying attention to purely practical issues. As a result, graduates were not able to apply the acquired knowledge in practice, make an independent decision, formulate and defend their own point of view, work in a team. Nevertheless, the students firmly knew: after graduating from university, they will be employed. In the 90's the situation with employment was radically changed. With the centralized distribution was over, universities stopped preparing specialists for the national economy, and began to train in accordance with the state educational standards, including in the non-demanded specialties. With the centralized distribution, it was finished, universities stopped preparing specialists for the national economy, and began to train in accordance with the state educational standards, including those on non-demand specialties. It became a norm that graduates do not work in their specialty, and some of them are registered annually as unemployed in the employment service. The self-worthiness of diplomas has increased as a way to avoid service in the army and as a means to get a job without any special knowledge [13; 14, p.72].

Enterprises began to practice the selection of personnel giving preference to persons with at least 3 years of experience. Since the mechanism of medium-term forecasting of Makhachkala and Dagestan economy needs, in workers and specialists has not been developed yet. Institutions of vocational education in determining the scope and profile of training specialists are forced to focus on social demand, rather than on the real needs of the labor market. As a result of this, the young people full strength and energy were left without work, and employment services are forced to engage in retraining people, who have just completed their studies and have received diplomas confirming their high level of qualifications $[15 ; 16]$. Enterprises simply stopped focusing on graduates of universities as specialists. They rather see a cheap labor force in them ready to work for wages, which is lower than the standard requests of employees with experience. Therefore, enterprises employees call conscientiousness and responsibility to be the most significant qualities of graduates.

The introduction of a competitive procedure for the placement of a state task for the training of specialists with higher professional education, obviously, will change the relations of higher education institutions - enterprises. Now, in order to obtain budgetary places, accredited higher educational institutions should take part in the competition for receiving government contracts, and to conclude agreements with organizations-users of personnel on the admission stated control numbers.

Having considered the attitude of various subjects in the educational space at the present stage, the authors come to the conclusion that the state educational policy in modern Russia is more monosubject than polysubject. To become polysubject, the education development policy should be aimed at satisfying the natural and inalienable right of every person - the right to receive education, taking into account individual characteristics, interests and abilities of the individual [10, p.8].

\section{Лumepamypa}

1. Билалов М.И. Студенческое мнение о социогуманитарном образовании в Дагестане. Дагестанский социологический сборник. Махачкала, 2005.

2. Всемирная Декларация о высшем образовании для 21 века: подходы и практические меры. Сборник документов, касающихся международных аспектов высшего образования. СПБ., 2000.

3. Ислам и исламская культура в Дагестане // Мусульманская система образования в 
Дагестане. М., 2001.

4. Коджаспирова Г.М. Педагогика в схемах, таблицах и опорных конспектах. М., 2008.

5. Конституция Российской Федерации. СПБ., 2001.

6. Концепция модернизации российского образования на период до 2010 года. Официальные документы в образовании. 2002. № 11.

7. Магидов Х.Г. Очерки краткой истории развития образования в Дагестане. Махачкала, 1998.

8. Методологические разработки по воспитательной работе. Из истории науки и школьного образования Дагестана. Махачкала,1989.

9. Об образовании. Закон РФ. Официальные документы в образовании. 2012.

10. Психология и педагогика. Учебное пособие // под редакцией А.А. Бодалева. М., 2002.

11. Садовничий В.А. Знания и мудрость в глобализирующемся мире. Доклад ректора МГУ им. М.В. Ломаносова на пленарном заседании IV Российского Международного конгресса (24 мая, 2005г. МГУ Москва). М., 2005.

12. Шипилов А. Зарплата российского профессора в прошлом, настоящем и будущем. Alma mater. 2003.

13. Drobotya N., Chaplygina E., Kamalova O., Sklyarova E. Drobotya N., Chaplygina E., Kamalova O., Sklyarova E. Contribution of researchers of Rostov state medical university to health development of Black Sea region // Научный альманах стран Причерноморья. 2017, № 1 (9).

14. Mustafaeva M., Mustafaev F., Mustafaev M. Comparative analysis of modern Dagestan student youth value orientations // Научный альманах стран Причерноморья. 2016, № 4 (8). C. 69-73,

15. Mustafaeva G., Mustafaev M. Role of ethno-confessional factor in international communication in regions of traditional Islam spread // Научный альманах стран Причерноморья. 2017. № 1 (10).

16. Petrova Yu.A. Language consciousness as the peculiarity of cultural differences// Научный альманах стран Причерноморья // Научный альманах стран Причерноморья. 2016. № 2.

\section{References}

1. Bilalov M.I. Student opinion on social and humanitarian education in Dagestan. Dagestan sociological collection. Makhachkala, 2005.

2. World Declaration on Higher Education for the 21st Century: Approaches and Practical Measures. Collection of documents on international aspects of higher education. SPb., 2000.

3. Islam and Islamic Culture in Dagestan // The Muslim Education System in Dagestan. M., 2001.

4. Kodzhaspirova G.M. Pedagogy in schemes, tables and supporting abstracts. M., 2008.

5. Constitution of the Russian Federation. SPb., 2001.

6. The modernization concept of Russian education for the period till 2010, Official documents in education. 2002. No 11.

7. Magidov Kh.G. Essays on a brief history of the education development in Dagestan. Makhachkala, 1998.

8. Methodological development of educational work. From the history of science and school education in Dagestan. Makhachkala, 1989.

9. About education. Law of the Russian Federation. Official documents in education. 2012.

10. Psychology and pedagogy. Textbook // edited by A.A. Bodaleva. M., 2002.

11. Sadovnichy V.A. Knowledge and wisdom in a globalizing world. Rector Report of the Moscow State University named after M.V. Lomanosov at the plenary session of the IV Russian International Congress (May 24, 2005 Moscow State University). Moscow, 
2005.

12. Shipilov A. Salary of the Russian professor in the past, present and future. Alma mater. 2003.

13. Drobotya N., Chaplygina E., Kamalova O. Researchers contribution of Rostov state medical university to health development of Black Sea region // Science Almanac of Black Sea region countries. 2017. No 1 (9).

14. Mustafaeva M., Mustafaev F., Mustafaev M. Comparative analysis of modern Dagestan student youth value orientations // Science Almanac of Black Sea region countries. 2016. No 4 (8).

15. Mustafaeva G., Mustafaev M. Role of ethno-confessional factor in international communication regions of traditional Islam spread // Science Almanac of Black Sea region countries. 2017. No 1 (10).

16. Petrova Yu.A. Language consciousness as the peculiarity of cultural differences // Science Almanac of Black Sea region countries. 2016. No 2. 